\title{
ДВОЙНАЯ ЭЛЕКТРИЧЕСКАЯ И МАГНИТНАЯ ПЕРЕСТРОЙКА ЧАСТОТЫ СВЯЗАННЫХ КОЛЕБАНИЙ В КОМПОЗИТНОМ МАГНИТОДИЭЛЕКТРИЧЕСКОМ РЕЗОНАТОРЕ
}

\author{
МОВЧАН Н. Н., ЗАВИСЛЯК И. В.
}

Киевский начиональный университет имени Тараса Шевченко, Украина, Киев, 01601, ул. Владимирская, 64/13

\begin{abstract}
Аннотация. Показана возможность двойной магнитной и электрической перестройки резонансных частот электродинамической структуры, состоящей из диэлектрического резонатора и гетероструктуры эпитаксиальная пленка железо-иттриевого граната/цирконат-титанат свинца. Теоретически и экспериментально исследованы связанные электромагнитно-спиновые колебания диэлектрического резонатора и эпитаксиальной пленки железо-иттриевого граната. Экспериментально показана возможность осуществления электрической перестройки частоты связанных колебаний композитного магнитодиэлектрического резонатора, которая обусловлена наведенными упругими напряжениями в эпитаксиальной пленке ЖИГ. Предложена теоретическая модель для расчета сдвига частоты связанных колебаний электрическим полем, приложенным к слою пьезоэлектрика. Показано, что собственная добротность композитного резонатора и диапазон электрической перестройки частоты гибридных колебаний возрастают при уменьшении поля подмагничивания
\end{abstract}

Ключевые слова: ?

?

\section{ВСТУПЛЕНИЕ}

Диэлектрические резонаторы находят широкое применение при создании частотно-избирательных устройств СВЧ. Перестройка резонансных частот существенно расширяет их функциональные возможности [1]. Изменение резонансной частоты диэлектрического резонатора осуществляется путем объединения высокодобротного диэлектрического резонатора, изготовленного из термостабильной керамики, со слоем материала, диэлектрическую или магнитную проницаемость которого возможно изменять внешним воздействием. При этом композитная электродинамическая структура должна иметь конструкцию, которая обеспечивает макси- мальную связь диэлектрического резонатора со слоем управляющего материала.

В качестве управляющего материала в составе композитного резонатора может использоваться ферроэлектрик, с управляемой электрическим полем диэлектрической проницаемостью [2], полупроводник с управляемой проводимостью ( $p-i-n$ диод) или полупроводник с управляемой шириной $p-n$ перехода (варакторный диод) [3]. Преимуществами выше приведенных методов управления резонансной частотой диэлектрических резонаторов являются малые инерционность и энергопотребление. Однако практическое применение перестройки частоты диэлектрического резонатора электрическим полем затруднено через значительное уменьшение (на 